\title{
Emerging OSH Issues in Installation and Maintenance of Floating Solar Photovoltaic Projects and Their Link with Sustainable Development Goals
}

\author{
Abhijit Sen (1)' \\ Akshay Shirish Mohankar \\ Abdulrahman Khamaj ${ }^{2}$ \\ Sougata Karmakar (iD) \\ 'Department of Design, Indian Institute \\ of Technology (IIT) Guwahati, Guwahati, \\ Assam, 781039, India; '2Department of \\ Industrial Engineering, College of \\ Engineering, Jazan University, Jazan, Saudi \\ Arabia
}

Objective: Emerging issues of occupational safety and health (OSH) in floating solar photovoltaic projects (FSPV) have rarely been addressed to achieve the Sustainable Development Goals (SDGs). The current scoping review has been planned to demonstrate OSH issues experienced by the workers engaged in the installation and maintenance of FSPV projects and existing ergonomics design interventions in the solar photovoltaic industry with a focus on the FSPV sector.

Methods: A literature review was conducted from four major electronic databases (Science Direct, Google Scholar, Web of Science, and Scopus) using predefined keywords and following the PRISMA framework for the period 1965-2020. A total of 49 studies under five headings, namely a) overview of key reasons for the emergence of floating solar photovoltaic projects, b) occupational risks of workers engaged in the solar PV industry/FSPV sector, c) occupational risks in workplaces/occupations similar to floating solar photovoltaics projects, d) availability of training modules and occupational standards, and e) design interventions/approaches in the solar PV industry/floating photovoltaics sector were analyzed.

Results: It emerged that workers are exposed to multifarious occupational risk factors such as heat, solar radiation, ergonomic risks, electrocution, fire, hazardous substances, adverse weather conditions, and psychosocial factors. These risks have not been adequately addressed with required interventions in the FSPV sector. Intervention opportunities include designing innovative tools, lowering of loads, redesigning workplace layouts, introducing job aids, automation, task rotation, job enlargement, design of training modules, OSH standards and changes in work organization/shift, etc.

Conclusion: This review is a first-of-its-kind effort to highlight the contextual risk factors in the emerging FSPV sector and the need for addressing them through ergonomics design interventions for successfully achieving the Sustainable Development Goals.

Keywords: floating solar PV, renewable energy, occupational safety and health, industrial design, ergonomics design interventions, sustainable development goals

\section{Introduction}

Increasing the share of renewable energy in the total energy mix is an important global priority for a decarbonized world. Among the many clean energy sources, utilizing the Sun's infinite power is a preferred option for countries where solar irradiation is high. Recent global growth in solar photovoltaic projects has been prompted due to climate change concerns, decreasing project costs, and greater adoption of clean energy by
Correspondence: Sougata Karmakar Department of Design, Indian Institute of Technology (IIT) Guwahati, Assam, 781039 , India

Tel +9l 36I-2582464

Email karmakar.sougata@gmail.com 
many countries to reduce greenhouse gas (GHG) emissions. An estimate by the International Renewable Energy Agency indicates that by 2050 , the share of solar photovoltaic generation would be $25 \%$ of the total global generation mix amounting to $8519 \mathrm{GW}$ with an anticipated investment of $\$ 132$ billion between the years 2019-50 and job creation for almost 18.7 million people. ${ }^{1}$ The different kinds of solar photovoltaic projects include ground-mounted, roof-top, canal-top, offshore, and floating. ${ }^{2}$ In recent years, floating solar photovoltaic (FSPV) projects have seen exponential growth because of their distinct advantages over other types of solar photovoltaic installations. FSPV projects have been shown to have a global potential of $400 \mathrm{GWp}^{3}$ These projects are implemented on lakes, ponds, reservoirs of dams and thermal power plants, water basins, mine quarries, water treatment plants, and over other water bodies.

\section{OSH Issues in the Installation and Maintenance of Floating Solar Photovoltaic Projects}

A significant portion of the installation and maintenance of FSPV projects involves manual work on both land and water. The occupational risks on land and water associated with a typical floating solar photovoltaic project are depicted in Figure 1. The workflow involves the unloading, transportation, and fabrication of unwieldy solar photovoltaic panels, gaskets, frames, bulky floats/pontoons, and electrical components. As a result, the workers are exposed to several occupational risk factors such as repetitive work, frequent bending, awkward postures, and handling heavy loads. These are potential occupational risk factors for developing Work-related musculoskeletal disorders. ${ }^{4}$ Such disorders include injuries to the nerves, muscles, joints, cartilages, ligaments, tendons, and other body parts. Some examples of such disorders include carpal tunnel syndrome, epicondylitis, and neck pain. ${ }^{5}$ Work-related musculoskeletal disorders (WMSDs) are linked to lost man-days, low productivity, and increased healthcare costs. ${ }^{6}$ A labor survey in the UK has revealed that 6.9 million working days were lost due to WMSDs in $2018 / 19$. $^{7}$

Work on a continually moving floating platform and high wind speeds put postural constraints on the workers. There are also possibilities of falling into water and exposure to an aquatic environment. Vibration can also be an occupational risk when using vibrating tools for assembling panels on frames/floats. The vibrating tools are also a source of noise which may lead to noise-induced hearing loss. ${ }^{4}$

During the anchoring and mooring process, divers may suffer from hypothermia and run the risk of drowning.

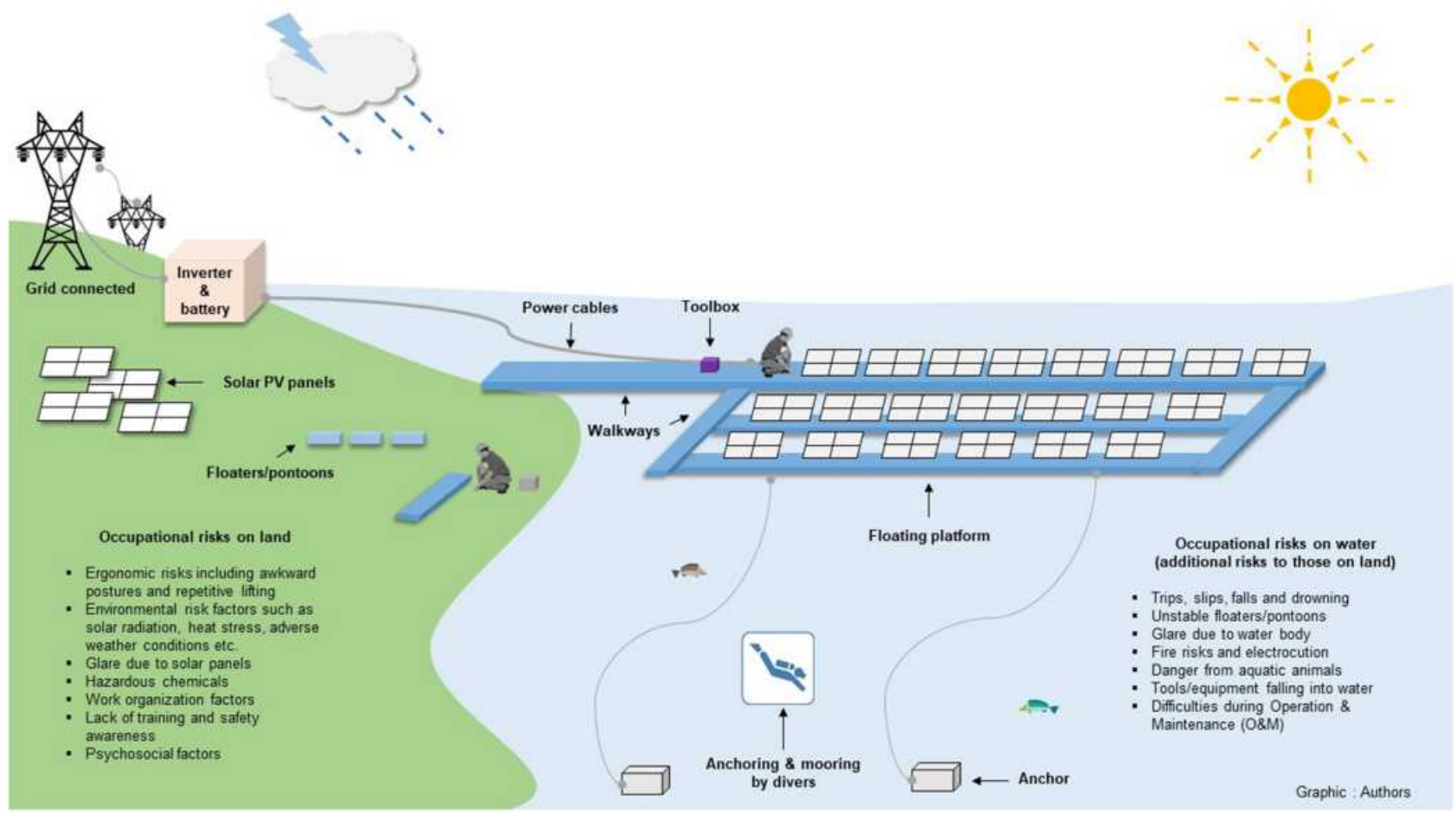

Figure I Schematic diagram of a typical floating solar photovoltaic project indicating the occupational risks on land and water. 
While installing solar panels on the floats, remotely located installation points may be unreachable, leading to work in confined spaces and chances of cuts and bruises from sharp objects/edges. Tools, clamps, and bolts may fall into the water, feet can get stuck into crevices between walkways and pontoons, and workers may trip due to connectors and cables laying around. During the commissioning and charging of the system, workers may be exposed to electrocution and fire hazards. Outdoor work for long hours in a hot and humid environment can lead to heat illnesses, dehydration, and fatigue. The workers can also experience glare from the solar panels' reflective surfaces and the surrounding water body. Glare may be direct or indirect and can degrade vision. ${ }^{5}$ Glare can also affect productivity by making it difficult for workers to install solar panels and associated components (inverters, wires, and cables) as visually demanding tasks are often involved in fixing bolts/nuts to assemble solar panels on the frames and connecting pontoons.

Installation is carried out during the day leading to prolonged exposure to solar radiation, which may have adverse effects on the skin, eyes, and immune system. ${ }^{8}$ The solar radiation is amplified by the reflection from the solar panels and the water body around the FSPV project. Adverse health effects of solar radiation include cataract, melanoma (affecting the eye), pterygium, macular degeneration, and skin cancer. ${ }^{8}$ Workers may be engaged in FSPV projects located on lakes/water bodies at high altitudes. Under such atmospheric conditions, there can be a reduction in the work capacity, and workers may suffer from the effects of cold stress. ${ }^{5}$

Since FSPV is an emerging sector requiring new skill sets, most workers are likely to be inexperienced and untrained. These factors can also lead to errors, which might result in injuries and even major accidents.

Predictive and preventive maintenance activities also carry several types of occupational risks. The presence of a water body around an electrical system (water and electricity do not mix) presents additional risks of falling into the water while cleaning or replacing the solar panels and other parts. Maintenance during rain, snowfall, during the night, or under extreme heat can cause serious illnesses. Floating solar photovoltaic projects are also exposed to risks from severe weather conditions. On September 9, 2019, a fire broke out in the 13.7 Megawatt Chiba Yamakura Floating Mega Solar Plant in Japan after a severe typhoon. ${ }^{9}$ The fire destroyed several solar panels and associated structures. Workers engaged in the repair and maintenance post such events are exposed to even more diverse and unknown occupational risks while removing and replacing damaged panels, floaters, and electrical equipment.

\section{OSH Aspects in FSPV Projects and Its Relationship with Sustainable Development Goals (SDGs)}

For an industry/sector to be sustainable, a safe and healthy workforce is an essential pre-requisite. The same is also true for the floating solar photovoltaic sector. The United Nations Development Programme (UNDP) has set seventeen Sustainable Development Goals (SDGs) to be attained by the year $2030 .{ }^{10}$ An important goal is to ensure the availability of affordable and clean energy (Goal 7). This objective is closely interlinked with the Paris Agreement on Climate Change reached in $2015,{ }^{1}$ where several countries have committed to a transition towards renewable energy. These global initiatives are key drivers for the rapid growth of the solar PV industry and the emergence of jobs in the solar PV value chain. Many SDGs are closely related to the OSH issues in the installation and maintenance of FSPV projects. They include Goal 3 (Good Health \& Well Being) and Goal 8 (Decent Work and Economic Growth). A framework depicting the $\mathrm{OSH}$ concerns in FSPV projects and their relationship with SDGs is shown in Figure 2. Ensuring the safety and health of the workers is a pre-requisite in attaining both Goals 3 and 8.

Compromising with OSH issues will ultimately affect the ability to provide clean and affordable energy and climate action since negative OSH outcomes have both direct and indirect costs. Moreover, components of SDGs are closely interlinked with each other.

Several studies have established the nexus between safety and sustainability. Gilding et al $^{11}$ emphasize using safety as a primary vehicle to achieve sustainability for human benefit and successful business practices. In a study among 251 manufacturing plants in Canada, safety culture was shown to be associated with indicators of performance linked to sustainable development. ${ }^{12}$ Jilcha and Kitaw ${ }^{13}$ mention that safe and healthy workplaces, innovation in workplaces, better knowledge of safety, and controlled environment are associated with sustainable development. Nawaz et $\mathrm{al}^{14}$ state the importance of considering the link between safety and sustainability based on several commonalities such as social, financial, and environmental 


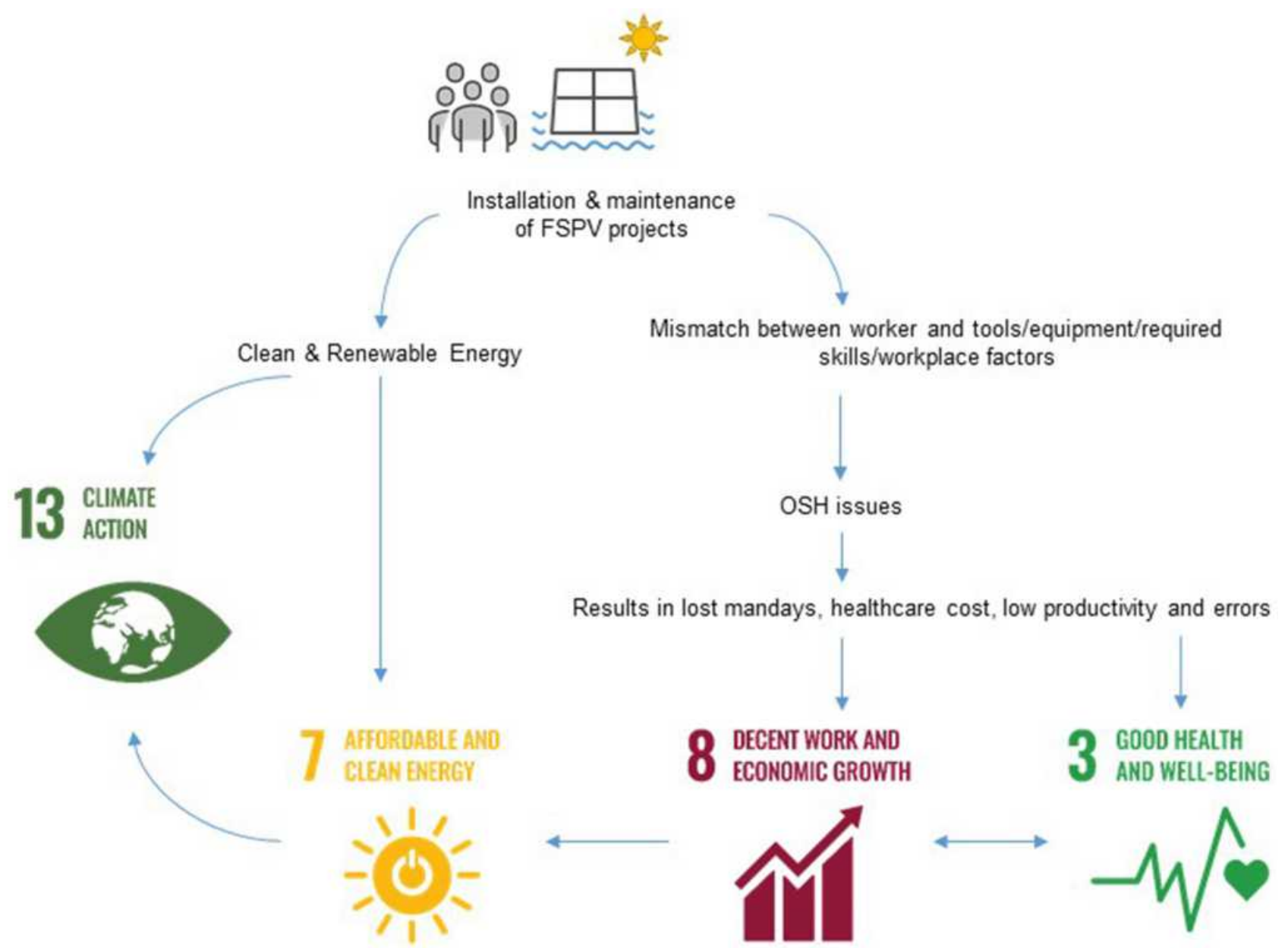

Figure 2 Interrelationships between OSH issues in installation and maintenance of FSPV projects and sustainable development goals (SDGs) of the United Nations Development Programme (UNDP).

factors. Therefore, addressing the OSH issues through appropriate interventions in the FSPV sector at the microlevel and solar PV industry as a whole must be an integral part of the efforts towards a sustainable and decarbonized world.

\section{Need for the Study}

Floating solar photovoltaic sites are new and emerging workplaces that are different from other kinds of solar photovoltaic installations but vastly different from industrial shop floors involving a combination of ergonomics factors. Occupational risks such as possibilities of collisions with objects, electrocution, slips, falls from height, strains, sprains, fire, mud, water, inclement weather, mechanical injury, and wildlife have been identified in solar PV plants. ${ }^{15}$ A report of the European Agency for Safety \& Health at Work (EU-OSHA) indicates that skill shortages are prevalent in the renewable energy industries due to fast-paced innovations. Thus, hazardous work is often carried out by less-skilled workers. ${ }^{16}$ This mismatch in skills and constantly changing workplace layouts are making the work more challenging, giving rise to several $\mathrm{OSH}$ issues. In addition, other emerging risks identified include non-standard work arrangements, weak OSH culture, hazards from nanomaterials, and issues related to the human-machine interface. ${ }^{16}$ According to another report by EU-OSHA, specific OSH risks related to installation, maintenance, and decommissioning of small scale solar energy projects include solar radiation, hazardous chemicals, fall from heights, slips and trips, awkward postures, new kinds of electrical risks (due to new technologies) and adverse weather conditions. ${ }^{17}$

Moreover, every new worksite may have its unique work organization, microclimate, and special skill sets requirements. This scenario gives rise to several concerns regarding the contextual occupational risks on account of 
the mismatch between man and machine. There is limited knowledge about the OSH aspects and existing ergonomics interventions in the fast-growing FSPV sector. Therefore, there is an urgent need to map the OSH aspects of the solar photovoltaic industry with a particular emphasis on the floating solar photovoltaic sector.

\section{Materials and Methods}

The review objective was to explore all risk factors influencing the workers engaged in FSPV projects from an OSH perspective and understanding existing approaches and future scope for addressing the problem areas. The review process started with formulating some research questions to understand the different aspects, especially in line with the present paper's objective. The research questions are as follows:

- Q1: What are the various features of FSPV projects and reasons for the growth of the sector in recent years?

- Q2: What are the different kinds of physical, chemical, environmental, psychosocial, and organizationrelated risks and their effect on workers in the floating solar photovoltaic sector and workplaces/occupations similar to the work environment (aquatic) of an FSPV project?

- Q3: Are training programs/modules and Occupational Safety \& Health (OSH) standards available for the FSPV sector?

- Q4: What are the existing design approaches in the solar PV industry (with emphasis on the FSPV sector) as prevention and/ or OSH risk mitigation strategy?

- Q5: What are the future opportunities for ergonomics design interventions in the FSPV sector?

In accordance with the review questions, search terms were defined, and a literature review was carried out by accessing the electronic databases of Science Direct, Google Scholar, Web of Science, and Scopus in a structured manner. The search period was selected from the year 1965 to 2020, and published papers in English were considered. The search terms and the various combinations used to identify online records were solar photovoltaics, floating solar photovoltaics, psychosocial risks, environmental risks, occupational health and safety standards, training, green jobs, work organization, ergonomics design interventions, design, aquaculture, shipyard workers, and occupational health and safety risks.
The current study presents a scoping review that has been carried out by referring to the guidelines for conducting scoping reviews using the Preferred Reporting Items for Systematic Reviews and Meta-Analyses (PRISMA) framework. $^{18}$ The step-by-step search methodology is depicted in the flowchart in Figure 3.

The inclusion criteria for the online search using the electronic databases of Science Direct, Google Scholar, Web of Science, and Scopus for shortlisting studies for the review was the presence of the search terms in the title, abstract, or keywords. The reference list of identified papers was also searched for additional studies. This resulted in the extraction of 193 studies. A total of 22 additional studies/ conference proceedings from other sources published by stakeholders/researchers in the solar photovoltaic industry and related $\mathrm{OSH}$ standards were also considered. These studies/resources were uploaded into a database manager, and duplicates were removed, resulting in 162 papers/ resources. These records were further screened, and repeated studies were excluded. A total of 54 papers were found eligible, and full texts were read. Some papers were further excluded as they were not specific to the review objectives. The online search resulted in the final shortlisting of 49 papers. The full papers were analyzed and divided into five broad headings, namely a) overview of key reasons for the emergence of floating solar photovoltaic projects, b) occupational risks of workers engaged in the solar PV industry/ FSPV sector, c) occupational risks in workplaces/occupations similar to floating solar photovoltaics projects, d) availability of training modules and occupational standards, and e) design interventions/approaches in the solar PV industry/floating photovoltaics sector. The future scope for each paper was also studied. Reports, textbooks, documents, and online news articles relevant to the present paper were also considered for highlighting different aspects. After the review of the papers, the outcome was compared to intervention approaches at various hierarchical levels to understand the knowledge gaps and opportunities for ergonomics design interventions. ${ }^{5}$

\section{Results}

The review has been arranged under the different broad headings, as mentioned in the methodology section. The data/information representing the key findings extracted from the shortlisted papers are discussed in the following sections. 

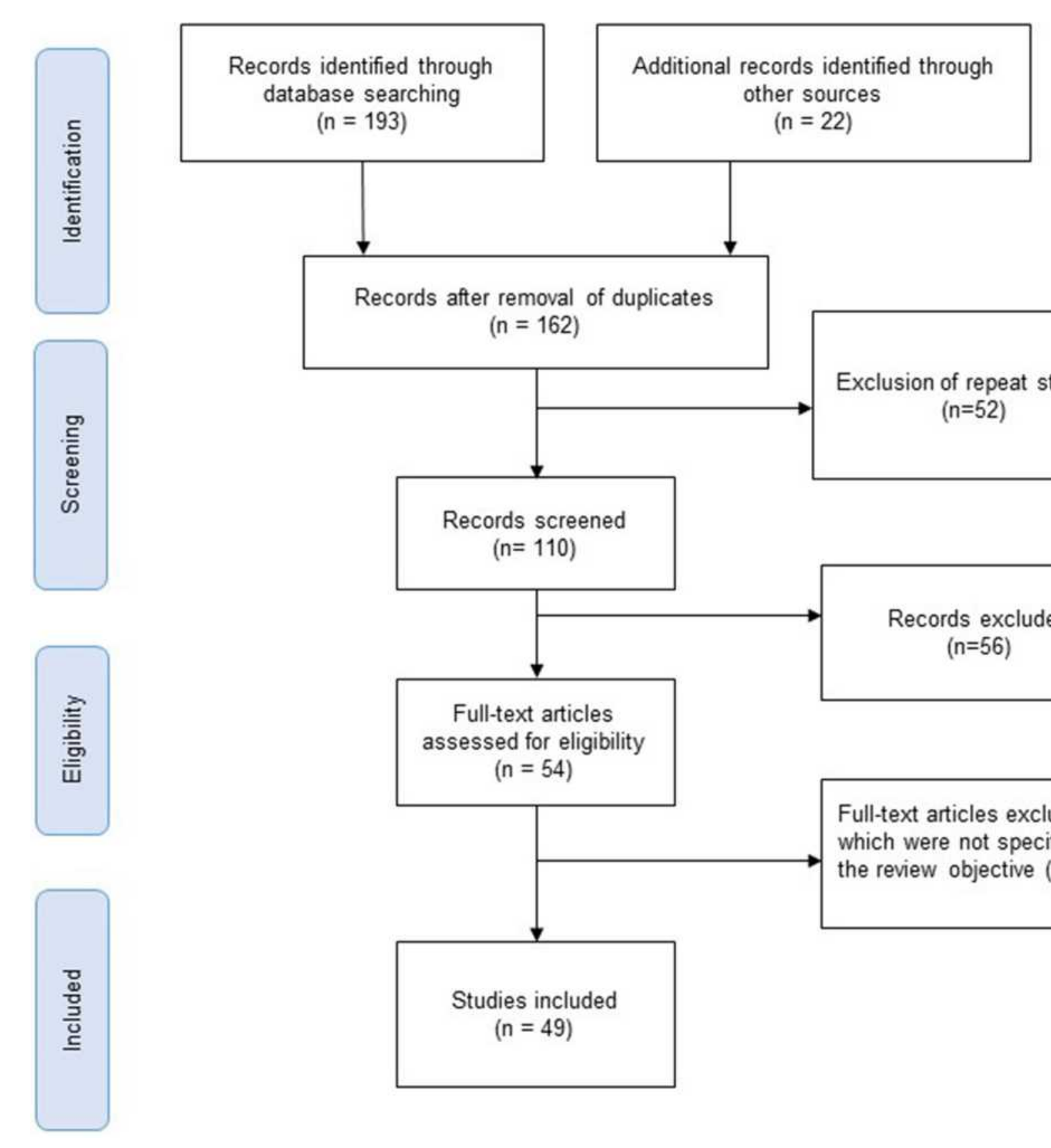

Records after removal of duplicates

$$
(n=162)
$$

\section{Additional records identified through} other sources

( $n=22$ )

Figure 3 Flowchart showing the various steps in the review process using the PRISMA framework. PRISMA figure adapted from Moher D, Liberati A, Tetzlaff J, Altman DG. Preferred reporting items for systematic reviews and meta-analyses: the PRISMA statement. Ann Intern Med. 2009;151:264-269. ${ }^{18}$

\section{Key Reasons for the Emergence of FSPV Projects}

A total of eleven studies concerned with the FSPV sector that captured the various aspects of floating solar PV projects were considered. The papers were reviewed and arranged according to the parameter, author, region of study, study type, and key findings. The findings/highlights are represented in Table 1.

\section{OSH Risk Factors Associated with Solar/ Floating Solar PV System}

Ten studies that contained the identification of occupational risks in the solar PV industry (emphasizing on floating solar photovoltaic projects) were reviewed. The gathered information was sorted and presented in terms of the occupational risk factors, authors, region, study type, findings, and future scope to mitigate the risks from an OSH perspective (Table 2). 
Table I A Summary of Key Reasons for the Emergence of Floating Solar Photovoltaic Projects

\begin{tabular}{|c|c|c|c|c|}
\hline Parameter & Author & Region & Study Type & Key Findings \\
\hline \multirow[t]{2}{*}{ Efficiency } & $\begin{array}{l}\text { Goswami et al, } \\
2019^{19}\end{array}$ & India & $\begin{array}{l}\text { Techno- } \\
\text { economic } \\
\text { analysis }\end{array}$ & Higher generating capacity as compared to ground-mounted solar PV \\
\hline & Liu et al, $2017^{20}$ & China & $\begin{array}{l}\text { Comparative } \\
\text { study }\end{array}$ & $\begin{array}{l}\text { Lower operating temperature as compared to ground-mounted solar PV } \\
\text { leading to better efficiency }\end{array}$ \\
\hline $\begin{array}{l}\text { Land } \\
\text { requirement }\end{array}$ & Sahu et al, $2016^{2}$ & NA & Review Study & Land neutral \\
\hline $\begin{array}{l}\text { Durability of } \\
\text { components }\end{array}$ & $\begin{array}{l}\text { Sahu and } \\
\text { Sudhakar, } 2019^{21}\end{array}$ & NA & Technical study & $\begin{array}{l}\text { Floating platforms (made of HDPE) are resistant to Ultraviolet exposure } \\
\text { and can bear loads of panels/accessories. }\end{array}$ \\
\hline \multirow[t]{3}{*}{$\begin{array}{l}\text { Water } \\
\text { conservation }\end{array}$} & $\begin{array}{l}\text { Azami } \\
\text { et al,2017 } 22\end{array}$ & Iran & $\begin{array}{l}\text { Theoretical } \\
\text { analysis }\end{array}$ & Reduced evaporation \& $\mathrm{CO}_{2}$ emission \\
\hline & $\begin{array}{l}\text { Mittal et al, } \\
2017^{23}\end{array}$ & India & $\begin{array}{l}\text { Numerical } \\
\text { analysis }\end{array}$ & Annual water saving of 191 million liters for a I MW project \\
\hline & $\begin{array}{l}\text { Rosa-Clot et al, } \\
2017^{24}\end{array}$ & Australia & Feasibility study & Saving of $15,000-25,000$ cubic meter of water per $M W_{p}$ \\
\hline $\begin{array}{l}\text { Economic } \\
\text { viability }\end{array}$ & $\begin{array}{l}\text { Ferrer-Gisbert } \\
\text { et al, } 2013^{25}\end{array}$ & Spain & Feasibility Study & Feasible on agriculture reservoir \\
\hline $\begin{array}{l}\text { Hybrid energy } \\
\text { system }\end{array}$ & $\begin{array}{l}\text { Cazzaniga et al, } \\
2019^{26}\end{array}$ & $\begin{array}{l}\text { Global } \\
\text { study }\end{array}$ & Data analysis & $\begin{array}{l}\text { Large potential for energy production when coupled with Hydro Power } \\
\text { Plants (HPPs) }\end{array}$ \\
\hline \multirow[t]{2}{*}{ Sustainability } & $\begin{array}{l}\text { Pringle et al, } \\
2017^{27}\end{array}$ & NA & Feasibility study & $\begin{array}{l}\text { FSPV combined with aquaculture can resolve food, energy and water } \\
\text { problems }\end{array}$ \\
\hline & $\begin{array}{l}\text { Trapani and } \\
\text { Miller, } 2013^{28}\end{array}$ & Malta & $\begin{array}{l}\text { Techno- } \\
\text { economic } \\
\text { analysis }\end{array}$ & Significant carbon savings \\
\hline
\end{tabular}

Note: NA: no specific mention of any particular region/country.

Abbreviations: HDPE, high-density polyethylene; MW, megawatt; MWp, megawatt peak.

\section{Occupational Risk Factors in Workplaces/ Occupations Similar to FSPV Sites}

As discussed earlier, the presence of water in the FSPV work environment presents additional occupational risks. Seven studies in workplaces/occupations such as aquaculture, shipping, lobstermen, and port workers were reviewed to understand the risks in occupations where the interface with water is involved. Aquaculture workers face several ergonomic, physical, biological, and other work-related risks. ${ }^{39-42}$ Shipyard workers are at the risk of falling from heights, electrocution, fire, explosion, object-related injury, and drowning. ${ }^{43}$ Port workers are exposed to occupational risks from toxic substances, noise, dust, extreme temperature, vibration, and ultraviolet radiation. ${ }^{44}$ The task of mooring in FSPV projects where boats are used is similar to work involved in jobs such as lobster hunting. Lobstermen in the northeast of the USA were exposed to ergonomic risks such as force, awkward postures, and repetition, resulting in low back pain and discomfort in the hand and wrists. The researchers suggest using ergonomics interventions to help in the handling of materials. ${ }^{45}$ During the installation of FSPV projects; divers are engaged in the mooring process, load testing, and anchoring. The divers are required to work underwater (sometimes at significant depths depending on the water body) for prolonged periods which exposes them to several OSH risks. A study on South Korean fishery divers revealed that $84.7 \%$ of them showed symptoms of decompression sickness (DCS). ${ }^{46}$ FSPV workers are mostly engaged in outdoor work, which exposes them to long hours of solar radiation. A study on seafarers in Germany showed the incidence of actinic keratosis as 
Table 2 Occupational Risks of Workers Engaged in the Solar PV Industry/FSPV Sector

\begin{tabular}{|c|c|c|c|c|c|}
\hline $\begin{array}{l}\text { Occupational } \\
\text { Risk Factors }\end{array}$ & Author & Region & $\begin{array}{l}\text { Study Typel } \\
\text { Tool }\end{array}$ & Findings & $\begin{array}{l}\text { Future Scope/Safety } \\
\text { Measures }\end{array}$ \\
\hline \multirow[t]{2}{*}{ Heat } & $\begin{array}{l}\text { Kamenopoulos } \\
\text { and Tsoutsos, } \\
2015^{29}\end{array}$ & NA & $\begin{array}{l}\text { Operational } \\
\text { Risk } \\
\text { Management } \\
\text { tool }\end{array}$ & $\begin{array}{l}\text { Heat is an occupational risk during operation \& } \\
\text { maintenance. }\end{array}$ & $\begin{array}{l}\text { Safety measures, monitoring, } \\
\text { and PPE }\end{array}$ \\
\hline & $\begin{array}{l}\text { Samaniego- } \\
\text { Rascón et al, } \\
2019^{30}\end{array}$ & Mexico & $\begin{array}{l}\text { Wet-bulb } \\
\text { Globe } \\
\text { Temperature }\end{array}$ & Exposure exceeded recommended levels & $\begin{array}{l}\text { Acclimatization, training on } \\
\text { reporting of symptoms \& } \\
\text { work/rest schedule }\end{array}$ \\
\hline \multirow[t]{2}{*}{ Electrocution } & $\begin{array}{l}\text { White and } \\
\text { Doherty, } \\
2017^{31}\end{array}$ & Canada & $\begin{array}{l}\text { Hazard } \\
\text { assessment }\end{array}$ & Shock and arc flash hazards & $\begin{array}{l}\text { Use of insulated gloves and } \\
\text { PPE }\end{array}$ \\
\hline & Wybo, $2013^{32}$ & France & $\begin{array}{l}\text { Focus } \\
\text { Groups }\end{array}$ & Shock hazard during maintenance & $\begin{array}{l}\text { Insulating gloves and covering } \\
\text { of panels with light-proof film }\end{array}$ \\
\hline Ergonomic risks & $\begin{array}{l}\text { Bakhiyi et al, } \\
2014^{33}\end{array}$ & NA & Review & $\begin{array}{l}\text { Repetition, awkward postures, and sharp } \\
\text { edges }\end{array}$ & Appropriate work methods \\
\hline \multirow[t]{2}{*}{ Fire } & $\begin{array}{l}\text { Falvo and } \\
\text { Capparella, } \\
2015^{34}\end{array}$ & USA & Case studies & $\begin{array}{l}\text { Blindspot in protection device was the cause of } \\
\text { the fire }\end{array}$ & $\begin{array}{l}\text { Use of many small inverters \& } \\
\text { inspection of failure modes }\end{array}$ \\
\hline & $\begin{array}{l}\text { Dhere and } \\
\text { Shiradkar, } \\
2012^{35}\end{array}$ & NA & Case studies & $\begin{array}{l}\text { Causes include open circuit, ground fault, and } \\
\text { arching }\end{array}$ & $\begin{array}{l}\text { Proper installation, safety } \\
\text { regulations, avoiding chimney } \\
\text { effect, etc. }\end{array}$ \\
\hline \multirow[t]{2}{*}{$\begin{array}{l}\text { Hazardous } \\
\text { substances }\end{array}$} & $\begin{array}{l}\text { Fthenakis and } \\
\text { Moskowitz, } \\
2000^{36}\end{array}$ & NA & $\begin{array}{l}\text { Safety \& } \\
\text { Health study }\end{array}$ & $\begin{array}{l}\text { Presence of chemicals in solar panels, } \\
\text { batteries, and inverters are potential sources }\end{array}$ & $\begin{array}{l}\text { Sustainable manufacturing, } \\
\text { PPE, employee training, and } \\
\text { safety procedures. }\end{array}$ \\
\hline & $\begin{array}{l}\text { Aman et al, } \\
2015^{37}\end{array}$ & NA & $\begin{array}{l}\text { Life Cycle } \\
\text { Assessment }\end{array}$ & $\begin{array}{l}\text { Presence of } \mathrm{NH}_{3} \text {, acetone, } \mathrm{As}, \mathrm{Si}, \mathrm{Pb}, \mathrm{HNO}_{3} \text {, } \\
\mathrm{Cd}, \mathrm{SF} 6, \mathrm{PBBs}, \mathrm{PBDEs}, \mathrm{HCl}, \mathrm{H}_{2}, \mathrm{Cr}-\mathrm{VI} \text {, } \\
\text { Isopropanol, Toluene, Xylene and } \\
\text { I, I, I-Trichloroethane }\end{array}$ & $\begin{array}{l}\text { Substitution of dangerous } \\
\text { materials, eco-friendly } \\
\text { manufacturing, and safe } \\
\text { disposal }\end{array}$ \\
\hline Psychosocial & $\begin{array}{l}\text { Fernandez et al, } \\
2017^{38}\end{array}$ & USA & Data Analysis & $\begin{array}{l}\text { Job insecurity and work-life imbalance in green } \\
\text { jobs }\end{array}$ & $\begin{array}{l}\text { Surveillance of occupational } \\
\text { psychosocial risks, protective } \\
\text { interventions, and company } \\
\text { policies }\end{array}$ \\
\hline $\begin{array}{l}\text { Lighting, hail, } \\
\text { typhoons, } \\
\text { strong winds, } \\
\text { and flora }\end{array}$ & $\begin{array}{l}\text { Kamenopoulos } \\
\text { and Tsoutsos, } \\
2015^{29}\end{array}$ & NA & $\begin{array}{l}\text { Operational } \\
\text { Risk } \\
\text { Management } \\
\text { tool }\end{array}$ & Work environment hazards & $\begin{array}{l}\text { Design interventions to } \\
\text { address the OSH risks }\end{array}$ \\
\hline
\end{tabular}

Note: NA: no specific mention of any particular region/country.

Abbreviations: PPE, personal protective equipment; $\mathrm{NH}_{3}$, ammonia; As, arsenic; $\mathrm{Si}$, silicon; Pb, lead; $\mathrm{HNO}_{3}$, nitric acid; Cd, cadmium; $\mathrm{SF}$, sulphur hexafluoride; PBBs, polybrominated biphenyls; PBDEs, polybrominated diphenyl ethers; $\mathrm{HCl}$, hydrochloric acid; $\mathrm{H}_{2}$, hydrogen; Cr-VI, hexavalent chromium.

a result of occupational exposure to sunlight. ${ }^{47}$ A high exposure to solar UV radiation was found in a study on fishermen in North Italy engaged in three types of fishing activities. $^{48}$

\section{Training Aspects and OSH Standards}

A review of seven studies and some OSH standards reveal several dimensions of training and OSH standards in the solar PV industry. A need for skill development 
programs for installers, training of users and technicians, capacity building programs, and technically qualified installers are required. ${ }^{49-52}$ The need for universal training modules with local improvisations was felt. ${ }^{49}$ Easy availability of skilled technicians (from the vicinity of the project) will ensure the successful implementation of the solar PV project, especially in rural areas. In addition, training needs and content for users/technicians may differ from project to project in terms of technology, design, layout, and other local factors. Hence, training of the local technical personnel and users were found to be crucial in achieving the success of rural solar PV projects. ${ }^{49}$ Some available training programs include the Training of Photovoltaic Installers (PVTRIN), which is an accreditation and training scheme for some European countries for personnel engaged in small-scale PV systems. ${ }^{53}$ The paucity of education and training has also been identified as a barrier in the renewable energy industry, resulting in a shortfall of qualified personnel in many countries. ${ }^{54}$

In this review, some OSH standards were found, like the National Standards on Health \& Safety at solar PV power plant, formulated by the Skills Council for Green Jobs in India. ${ }^{55}$ Regulations of the Occupational Safety and Health Administration (OSHA) applicable to PV installations are covered in a) Occupational Safety and Health Standards (Part 1910) and b) Safety and Health Regulations for Construction (Part 1926). ${ }^{56}$ The Queensland Code of Practice is aimed at the safety and health of workers associated with the life cycle of solar farms. ${ }^{57}$ The code emphasizes the need to design safe solar farms by removing hazards at the planning and design stage. It recommends that design engineers associated with solar farms should acquire requisite competencies (such as health and safety rules, risk management, design standards, etc.) to minimize occupational safety and health risks. The Newport Beach Fire Department has specified standards for designing layouts and installing roof-top solar PV projects to ensure fire safety. ${ }^{58}$ The Newport Beach Fire Department's guidelines recommend the provision of walkways and marking of PV components. The walkways or sufficient clearance space along the solar PV installation-frames help the workers in safe and comfortable movement under various postures during installation and maintenance activities. Besides, these walkways also serve as escape routes for the evacuation of workers during exigencies.

\section{Design Interventions/Approaches in the Solar PV Industry}

One of the objectives of this present review is to understand opportunities for ergonomics design interventions in the FSPV sector to address the emerging OSH issues. Therefore, in order to understand the existing design approaches (for identifying research gaps) in the solar PV industry, fourteen papers were reviewed. The different design approaches in the solar PV industry are depicted in Table 3. The studies considered are arranged in terms of author, region, type of solar PV project/product, type of study, design scope, and design objective.

\section{Research Gap and Opportunities for Ergonomics Design Interventions}

The scoping review and its subsequent comparison with the intervention approach at various hierarchical levels are shown in Figure 4. The different types of intervention approaches have been taken from Bridger, 2018..$^{5}$ It was revealed that although some studies and interventions have addressed the multifarious occupational risks (indicated by blue lines) in the solar PV industry in general, most of the occupational risks (indicated by broken red lines) remain unaddressed. No study was found that addressed or proposes to address the OSH issues in the floating solar PV sector from an ergonomics design perspective. This presents a vast opportunity for adopting design intervention strategies at a stage when the FSPV industry is nascent and expanding fast. These circumstances are likely to make stakeholders more responsive to adapting and implementing these opportunities to ensure the workforce's OSH.

The research gaps (indicated as broken red lines in Figure 4) or the unexplored interventions can be divided into bottom-up, top-down, and same-level interventions (refer to Figure 5). Bottom-up interventions include a) lowering of loads, b) redesigning of layout, c) provision of job aids, and d) changing tools. Top-down interventions include a) automation, b) task rotation) job enlargement and d) change in work organization. Same level interventions include a) workplace redesign and b) improvement in the work environment. The intervention strategy/plan will depend on FSPV project design, duration, location, type of equipment and materials used, work organization, funding, the involvement of top management, safety policy, statutory and local regulations, and most importantly, commitment to affirmative action on Occupational Safety \& Health. A majority of 
Table 3 Design Approaches in the Solar PV Industry

\begin{tabular}{|c|c|c|c|c|c|}
\hline Author & Region & $\begin{array}{l}\text { Type of } \\
\text { Solar PV }\end{array}$ & Study Type & Design Scope & Design Objective \\
\hline Dai et al, $2020^{59}$ & Singapore & FSPV & Performance analysis & $\begin{array}{l}\text { Efficiency, load-bearing ability, durability, } \\
\text { and easy operation \& maintenance }\end{array}$ & $\begin{array}{l}\text { Better structural \& } \\
\text { operational performance }\end{array}$ \\
\hline Ho et al, $2020^{60}$ & USA & Roof-top PV & Case studies & $\begin{array}{l}\text { Prevention-through Design protocol \& } \\
\text { attributes }\end{array}$ & Workplace safety \\
\hline Li et al, $2020^{61}$ & Australia & Roof-top PV & Simulation & Design of roof & Efficiency \\
\hline Bao et al, $2020^{62}$ & USA & $\begin{array}{l}\text { Solar PV } \\
\text { installations }\end{array}$ & $\begin{array}{l}\text { Survey of } \\
\text { stakeholders \& } \\
\text { homeowners }\end{array}$ & Human-Centered Design & Adaptability of solar PV \\
\hline $\begin{array}{l}\text { Hernández- } \\
\text { Callejo et al, } \\
2019^{63}\end{array}$ & NA & $\begin{array}{l}\text { Solar PV } \\
\text { installations }\end{array}$ & Review & Design, operation \& maintenance & $\begin{array}{l}\text { Increased efficiency and } \\
\text { lower costs }\end{array}$ \\
\hline Hong, $2019^{64}$ & NA & $\begin{array}{l}\text { Solar PV } \\
\text { products }\end{array}$ & $\begin{array}{l}\text { TRIZ innovation } \\
\text { method }\end{array}$ & Design elements for better usability & Sustainable products \\
\hline $\begin{array}{l}\text { Cazzaniga et al, } \\
2018^{65}\end{array}$ & Italy & FSPV & Performance analysis & Innovation in PV system design & $\begin{array}{l}\text { Increased efficiency and } \\
\text { lower costs }\end{array}$ \\
\hline $\begin{array}{l}\text { Bhang et al, } \\
2018^{66}\end{array}$ & $\begin{array}{l}\text { South } \\
\text { Korea }\end{array}$ & FSPV & Predictive analysis & Use of grounding electrodes & Electrical safety \\
\hline Bao et al, $2017^{67}$ & USA & Roof-top PV & Consumer survey & Visual appearance of solar panels & $\begin{array}{l}\text { Influencing the } \\
\text { preference of solar } \\
\text { panels }\end{array}$ \\
\hline Kim et al, $2017^{68}$ & $\begin{array}{l}\text { South } \\
\text { Korea }\end{array}$ & FSPV & $\begin{array}{l}\text { Tech-commercial } \\
\text { analysis }\end{array}$ & Design \& construction of FSPV system & Cost-effectiveness \\
\hline $\begin{array}{l}\text { Balo and } \\
\text { Șağbanșua, } \\
2016^{69}\end{array}$ & NA & Solar panel & AHP & Solar panel characteristics & $\begin{array}{l}\text { Influence on purchase } \\
\text { decision }\end{array}$ \\
\hline $\begin{array}{l}\text { Scognamiglio, } \\
2016^{70}\end{array}$ & NA & Ground PV & Ecological impact & Land-integrated photovoltaics & Ecological performance \\
\hline Lee et al, $2014^{71}$ & $\begin{array}{l}\text { South } \\
\text { Korea }\end{array}$ & FSPV & Performance analysis & The material of floating platform & Durability \\
\hline $\begin{array}{l}\text { Spertino and } \\
\text { Corona, } 2013^{72}\end{array}$ & $\begin{array}{l}\text { Turin, } \\
\text { Italy }\end{array}$ & $\begin{array}{l}\text { Roof-top \& } \\
\text { Ground PV }\end{array}$ & $\begin{array}{l}\text { Techno-economic } \\
\text { analysis }\end{array}$ & $\begin{array}{l}\text { Design of guidelines for PV system, } \\
\text { maintenance \& installation }\end{array}$ & Energy Efficiency \\
\hline
\end{tabular}

Note: NA: no specific mention of any particular region/country.

Abbreviations: AHP, analytical hierarchy process; TRIZ, theory and inventive problem solving.

the work associated with FSPV plants involves significant Manual Material Handling (MMH), including the transportation of solar PV panels, lifting of floaters, assembling of pontoons/panels, and construction of scaffoldings. These activities involve awkward postures, and working on a continually swaying floating platform near water. These tasks can be optimized by primarily attempting bottom-up design interventions that are relatively easier to implement and require relatively little investment. This is especially important when the installation of FSPV projects is of short duration and involves a large workforce. Top-down interventions such as automation will require huge investments, while task rotation/job enlargement will be difficult to implement in 


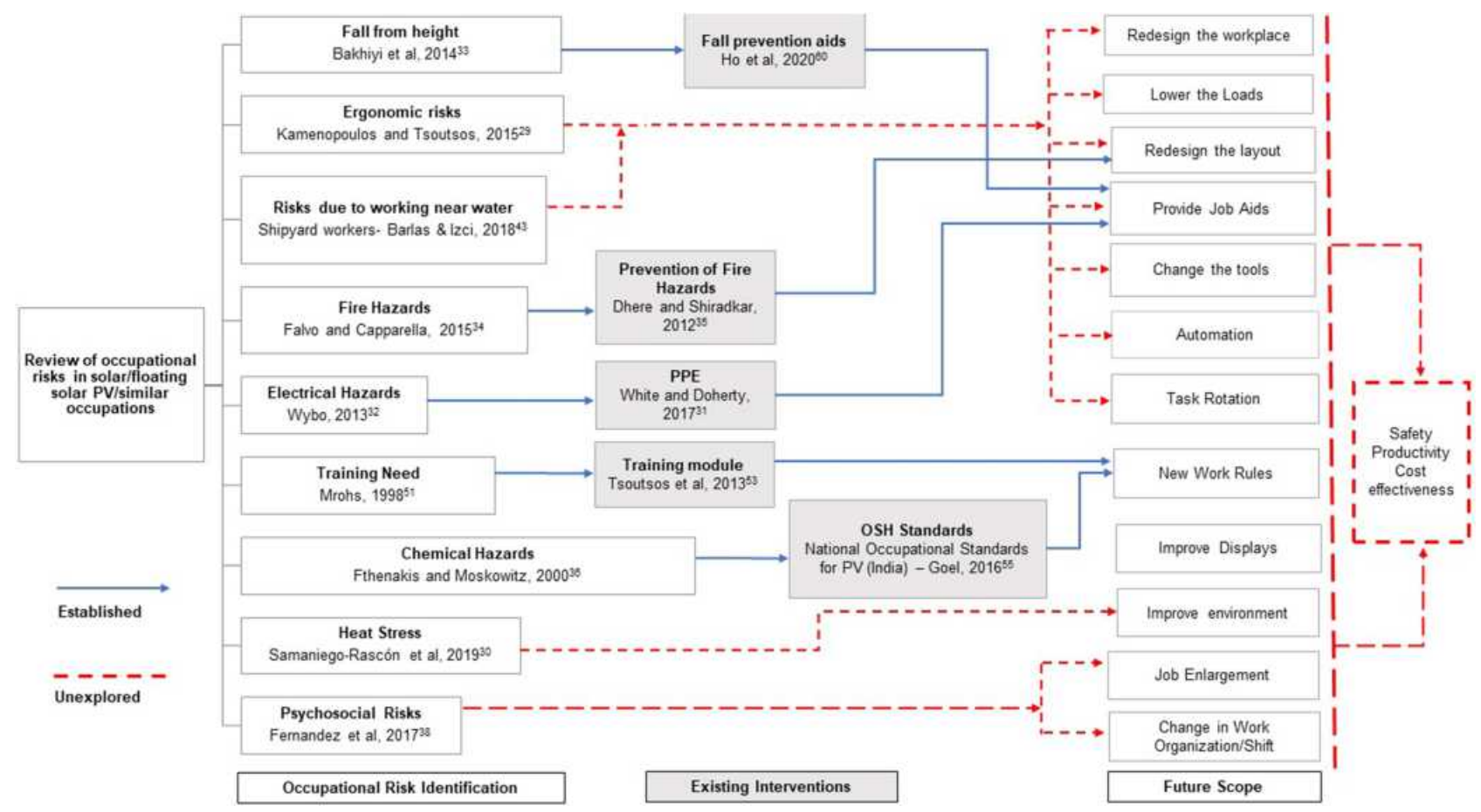

Figure 4 Risk identification, existing interventions, and opportunities for ergonomics design interventions at various levels as revealed from the review. (Studies and author names are indicative and not exhaustive).

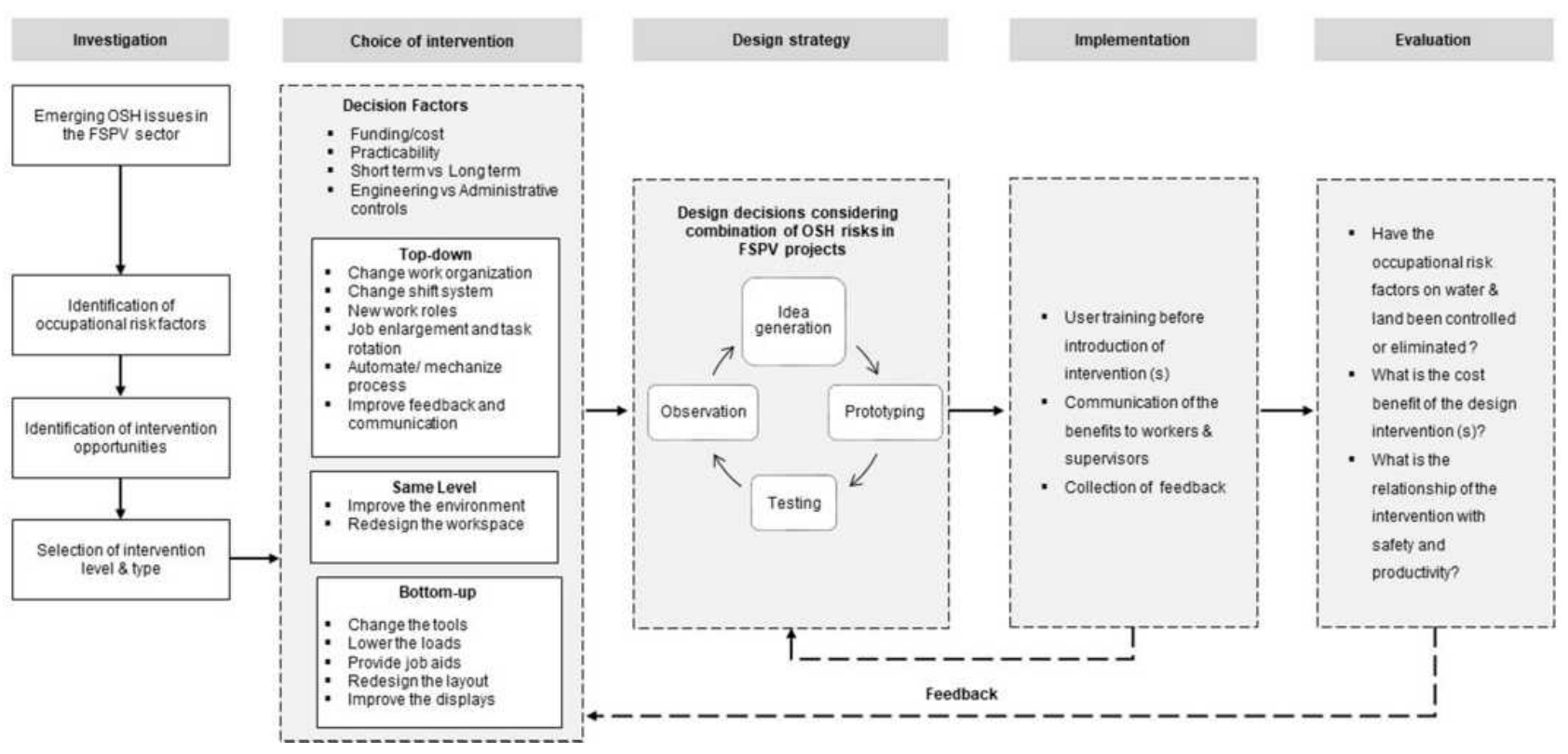

Figure 5 A proposed strategy for implementing design interventions in the FSPV sector.

Notes: Types and levels of interventions (under choice of intervention in the figure) data from Bridger ${ }^{5}$ and 'steps in the design process' (under design strategy in the figure) data from Norman. ${ }^{73}$

unstructured jobs, which are distinctively different from assembly line layouts. Controlling the sources of the risk in outdoor working environments such as high temperatures and solar radiation is challenging.
Therefore, appropriate Personal Protective Equipment (PPE), provision of shade/shelters, availability of drinking water, heat acclimatization, and design of work-rest cycles (avoiding work during the hottest part of the day) 
Table 4 Man-Machine Interfaces Involved in Floating Solar PV Plants, Occupational Risk Factors, Occupational Diseases, and Proposed Scope for Ergonomics Design Interventions

\begin{tabular}{|c|c|c|c|}
\hline $\begin{array}{l}\text { FSPV System } \\
\text { Components }\end{array}$ & $\begin{array}{l}\text { Occupational Risk } \\
\text { Factors }\end{array}$ & $\begin{array}{l}\text { Occupational Diseases/ } \\
\text { Conditions* }\end{array}$ & Design/Redesign Scope \\
\hline Solar PV panel & $\begin{array}{l}\text { Awkward postures } \\
\text { during installation \& } \\
\text { unwieldy equipment. }\end{array}$ & $\begin{array}{l}\text { Low Back Pain (LBP) \& } \\
\text { Musculoskeletal disorders (MSDs) }\end{array}$ & Lowering of loads and task rotation \\
\hline Frames, clamps/nuts/bolts & $\begin{array}{l}\text { Sharp edges and sub- } \\
\text { optimal designs }\end{array}$ & Cuts, bruises, strains, and WMSDs & Layout redesign, lowering of loads \\
\hline $\begin{array}{l}\text { Water bodies, pontoons/ } \\
\text { floating structures, and } \\
\text { walkways }\end{array}$ & $\begin{array}{l}\text { Unstable platform/Wet- } \\
\text { work exposure. }\end{array}$ & $\begin{array}{l}\text { Irritant Contact Dermatitis (ICD), } \\
\text { slips, trips, drowning, and even } \\
\text { fatalities }\end{array}$ & $\begin{array}{l}\text { Workplace redesign, training, and Personal } \\
\text { Protective Equipment (PPE) }\end{array}$ \\
\hline $\begin{array}{l}\text { Tools such as hammers, } \\
\text { pliers, cutters, wire } \\
\text { strippers, and manual } \\
\text { cleaning equipment }\end{array}$ & $\begin{array}{l}\text { Awkward \& repetitive } \\
\text { postures, noise, } \\
\text { vibration, compression, } \\
\text { and usability issues }\end{array}$ & $\begin{array}{l}\text { Carpal tunnel syndrome, tendinitis, } \\
\text { MSDs, cuts, bruises, and Hand Arm } \\
\text { Vibration syndrome }\end{array}$ & Design/redesign of tools and/or PPE \\
\hline $\begin{array}{l}\text { Batteries, panels, and } \\
\text { inverters }\end{array}$ & $\begin{array}{l}\text { Toxic oxides and } \\
\text { electrocution }\end{array}$ & $\begin{array}{l}\text { Injury, burns, and even death from } \\
\text { electrocution }\end{array}$ & Job aids/PPE \\
\hline $\begin{array}{l}\text { Cranes, connectors, wires } \\
\& \text { cables }\end{array}$ & $\begin{array}{l}\text { Objects may fall, fall from } \\
\text { height, slips, and } \\
\text { electrocution }\end{array}$ & Head injuries and electrocution & PPE/Workplace redesign \\
\hline Work environment & $\begin{array}{l}\text { Heat, UV radiation, } \\
\text { humidity, rain, snow, } \\
\text { noise, dust, etc. }\end{array}$ & $\begin{array}{l}\text { Heat illnesses, tinnitus, slips, falls, } \\
\text { respiratory diseases, immune system } \\
\text { disorders, skin cancer, and diseases of } \\
\text { the eyes }\end{array}$ & $\begin{array}{l}\text { Improvement in the environment, design of } \\
\text { PPE, skin protective clothing, head \& eye } \\
\text { protection products, sun-safety training/ } \\
\text { awareness programs, and health monitoring }\end{array}$ \\
\hline Work organization & Psychosocial & Job stress and absenteeism & $\begin{array}{l}\text { Training, job design, shift rotation \& job } \\
\text { enlargement }\end{array}$ \\
\hline
\end{tabular}

Note: *Data from Stack and Ostrom, ${ }^{4}$ Bridger, $^{5}$ and Modenese et al. ${ }^{8}$

can resolve the issues. Protecting the workers from the effects of solar radiation is critically essential. Explorations of designing the head and eye protection products, developing protective clothing for covering the skin, conducting awareness programs on the adverse health effects of solar radiation, and imparting training among the workers are required for this purpose. As discussed earlier, various aspects of the FSPV system can be considered for design and redesign.

The different man-machine interfaces in a typical FSPV workplace, occupational risk factors, occupational diseases, and proposed future scope from an ergonomics design perspective are shown in Table 4 . This will allow interested stakeholders to understand specific areas of intervention better and analyze their relationship with safety, productivity, and cost-effectiveness.

\section{Discussion}

This scoping review was carried out to understand the reasons for the emergence of FSPV projects and OSH issues in the emerging FSPV sector. It aimed to find out whether those issues have been appropriately addressed and the future scope for interventions from an ergonomics design perspective to aid in successfully attaining the related Sustainable Development Goals (SDGs). We discuss the findings of this review in the following sections to get a holistic picture of existing research and the way ahead.

\section{The Emergence of FSPV Projects}

A major reason for the emergence of FSPV projects is that they do not require land acquisition (land acquisition is a sensitive socio-economic issue in many countries). ${ }^{2}$ 
There is also an abundance of water reservoirs and other water-bodies globally. Moreover, FSPV is more efficient than ground-mounted SPV. ${ }^{19}$ It can be combined with hydroelectric plants ${ }^{26}$ and reduces evaporation while protecting the aquatic environment apart from other advantages. A review study informs that combined use of FSPV and aquaculture will help in moving towards a sustainable green economy by fulfilling the needs of water, energy, and food and preservation of the ecosystem. ${ }^{27}$

FSPVs can also help in environmental protection by reducing coal consumption. A 10 Megawatt FSPV plant study revealed that a huge quantity of coal could be saved along with the significant reduction of carbon dioxide emission during the lifetime of the plant. ${ }^{19}$ Hence, FSPV projects are becoming more and more preferred in many countries from a sustainability perspective.

Installation of FSPV projects involves a relatively higher cost due to floating platforms' construction, anchoring, and mooring. These are likely to be offset by better efficiency due to innovative designs and improved technology. ${ }^{74}$ In most FSPV projects, the material used in the manufacture of floaters/pontoons consists of Highdensity polyethylene. This material has been found to have an adequate load-bearing capacity and is resistant to ultraviolet radiation. ${ }^{21}$

The environmental impact of FSPV plants, in the long run, include deterioration of water quality, loss of aquatic species and avian habitat, loss of recreational value, and creation of waste (damaged panels, floaters, cables, batteries, etc.). ${ }^{3}$

\section{OSH Issues in the FSPV Sector}

The reviewed studies revealed the existence of various occupational risk factors. The problems mainly emanate from the mismatches between the capabilities of the workers and the workplace factors. The occupational risks from equipment/tools include electrocution, exposure to hazardous substances, fire, and ergonomic risks. ${ }^{31,33,36,37}$ The work environment's occupational risks include working for long hours in extreme temperatures and work requirements under strong winds, hail, typhoons, near/with water, etc. ${ }^{29,30}$

Solar PV projects are usually located in areas where solar irradiation is high and involves outdoor work. Therefore, heat stress is a critical occupational risk factor for solar workers. A report by the International Labour Organization (ILO) indicates that in 2030 heat stress is likely to result in a loss of $2.2 \%$ of the total global working hours. ${ }^{75}$ In a study on solar workers in Mexico, it was found that the conditions of work (heat-related) were beyond the recommended exposure limits. In the same study, it was also found that acclimatized workers had a higher work capacity than non-acclimatized workers, although all work had to stop during a heatwave. To avoid the ill effects of heat, the authors recommend scheduling heavy tasks for early morning and before evening. ${ }^{30}$ Kim and Lee $^{76}$ also inform that there is expected to be a loss in working capacity (ultimately affecting productivity) in 52 occupations in the Republic of Korea due to the rise in Wet-bulb Globe Temperature (WBGT) as a result of climate change. They recommend providing real-time information to workers to help them understand the causes and effects of heat stress. Apart from heat stress, the workers are also exposed to solar radiation.

The intensity of exposure is further increased by the reflection of sunlight from the solar photovoltaic panels and the surrounding water body on which the FSPV project is installed. This prolonged exposure can severely affect the eyes and the skin, thereby limiting working ability and years of working life. ${ }^{8}$

The long-term effects of occupational exposure to solar radiation also include different types of skin cancer. ${ }^{77}$ FSPV workers can be protected from the health effects of solar radiation (a human carcinogen) by providing shades, rest areas, breaks through job design, especially during the hottest part of the day, adequate sun-safety training on the ill effects of solar radiation, use of sunglasses, headgear, sunscreens, sun-protective clothing and medical check-ups for detecting early signs of cancer. ${ }^{8,78}$ With many workers entering the FSPV sector, these early interventions can help prevent both short-term and longterm health effects of solar radiation.

Bakhiyi et $\mathrm{al}^{33}$ report several ergonomic risks (eg, awkward postures and heavy loads lifting) may severely compromise the OSH of the workers. White and Doherty ${ }^{31}$ reported the safety issues involved with the installation and maintenance of solar PV panels. They mention the risk of electrocution from solar modules, inverters, and transformers. Other occupational risks to the personnel working with such systems include arc flash, wind speeds, fire, solar heating, and fall from elevated positions. Another potential risk is that the PV system cannot be turned off, and the solar panel may generate electricity in the presence of any light source. ${ }^{31}$ This aspect should be kept in mind, particularly by maintenance personnel 
engaged in cleaning and replacing solar panels. There are also increased risks of electrical leakage in FSPV sites due to a highly humid environment. ${ }^{3}$

Kamenopoulos and Tsoutsos ${ }^{29}$ followed the Operational Risk Management (ORM) methodology to identify three risk categories in the operation and maintenance of solar PV systems. These are namely natural (lighting, winds, dust, etc.), man-made (vandalism/theft), and technological (electrocution, fire, etc.). Aman et al $2015^{37}$ mention the toxic substances associated with different components of a solar PV installation which can cause adverse health effects. Ammonia used in solar PV modules can cause irritation to the skin and eyes. Arsenic can cause lung infection and can affect several other organs. Cadmium used in solar cells and Polybrominated biphenyls used in solar panel inverters are carcinogenic. Lead used in electrical components can damage the nervous system. ${ }^{37}$ In addition, other toxic substances mentioned in Table 2 also have deleterious health effects which need to be neutralized through interventions. Use of safe materials during manufacturing, design, and use of appropriate PPE during installation and maintenance, and safe disposal should be adopted for the workers' safety and health. According to a study, work-life imbalance and job insecurity were found as major psychosocial risk factors in green-collar jobs. ${ }^{38}$ Age, gender, wages, socioeconomic status, statutory requirements, history of injuries, and physiological capabilities of the workers should also be considered while deploying workers since they have an association with musculoskeletal diseases. ${ }^{4,79}$

FSPV workers are also exposed to risks from the microclimate, which might present extreme temperatures, exposure to toxic chemicals, excessive noise, and vibration from the use of tools/equipment. Cleaning of solar panels during maintenance and repair/replacement of floaters involves prolonged work with water. Prolonged wet-work is a potential risk factor for the development of occupational skin disorders, such as Irritant Contact Dermatitis, ${ }^{80}$ and necessary interventions should be adopted to prevent such disorders. Divers are exposed to several occupational risks of working underwater during installation for anchoring and mooring and also during maintenance. Even with self-contained underwater breathing apparatus (SCUBA), divers may suffer from decompression sickness (DCS) and face a hypothermic and hyperbaric milieu ${ }^{81}$

Adverse weather conditions such as lightning, hail and strong winds have been identified as a major risk factor for the workers. ${ }^{29}$ Inclement weather can also affect the FSPV installation itself. ${ }^{9}$ Suitable design interventions such as safety harness, storm shelters and PPE for occupational safety and health can be adopted to protect the workers. In addition, scheduling of installation and maintenance jobs should consider the weather forecast data and requisite safety training should be provided for emergency evacuation during such events. Also, several companies/manufacturers are designing FSPV projects so as to neutralize adverse weather events such as storms. ${ }^{82}$ We are of the view that if suitable preventive measures such as design interventions are adopted at the project sites, the workers can be provided with a safe working environment at different locations in spite of many challenges.

Thus, it can be deciphered that the occupational risks are multifarious and may affect the worker singly or in combination, creating unsafe conditions. No studies that measured or analyzed the occupational risks in the FSPV sector were found in this review.

\section{Perspectives from OSH Risks in Similar Occupations}

It emerges that many occupational risks are common between FSPV sites and other occupations/workplaces associated with an aquatic work environment (aquaculture, fishing, shipyard/port workers, etc.). They include prolonged wet-work, ergonomic risks, noise, dust, toxic substances, fall from heights, ultraviolet radiation, electrocution, vibration, and high temperatures.

FSPV workers are not only exposed to the already existing risks of the solar PV industry but run the risks from aquatic organisms, adverse water composition, possibilities of drowning, and possibly greater psychosocial risks. This makes risk mitigation in the FSPV sector even more critical. Future intervention scope may include continuous supervision and communication with divers, provision of rescue divers when diving activities are performed, surveillance, occupational risk awareness, risk minimization, and understanding occupational disease causation pathways.

\section{Need for Training and OSH Standards}

The review did not reveal the existence of training programs or universal OSH standards in this sector in particular. Lack of training modules and $\mathrm{OSH}$ standards specific to the floating solar sector also means that untrained workers are being exposed to complex and unknown work protocols. The assumption that prior 
work experience in the execution of roof-top and groundmounted solar PV projects would be sufficient may not be correct. A study has shown that workers' training is positively associated with occupational safety. ${ }^{83}$ Therefore, proper training before the deployment of workers is critical in avoiding unsafe acts and achieving efficient and error-free work. The mandatory inclusion of sun-safety training before deployment of FSPV workers should be considered both in training programs and $\mathrm{OSH}$ standards.

The successful adoption of sun-safety programs at the workplace depends on several internal, external, and other factors. The intervention model adopted for the "Sun Safety at Work Canada" program can be referred into when implementing such programs in the FSPV sector. ${ }^{84}$

Future scope includes the development of training programs with a focus on OSH for different types of solar PV projects since the contextual requirements are different. The authors also feel that universal OSH standards should be developed for the FSPV sector separately.

\section{Existing Design Approaches in the Solar PV Industry}

The outcomes of the review reveal that the majority of the research on floating solar PV projects is focusing on the design parameters related to efficiency, performance improvement, cost-effectiveness, the durability of the floaters, and other aspects. ${ }^{59,63,65,68,72}$ Little focus has been given to the design interventions in the FSPV sector from the dimension of OSH of the workers who are the most vulnerable and exposed to a complex combination of risks except for one study which focuses on electrical safety. ${ }^{66}$ The papers in this review reveal that most of the focus has been given to the OSH aspects of the small-scale roof-top solar PV projects and not so much to utility-scale land mounted or floating solar PV projects. The Oregon Solar Industries Association (OSEIA) has developed a detailed manual to ensure construction safety. ${ }^{85}$ The manual consists of ways in which occupational risks can be identified and removed or controlled if elimination is not possible and ways to recover from accidents. Although the manual can be beneficial during the construction phase, it does not offer any design solutions and is only restricted to roof-top solar installations. Similarly, the Nigerian Energy Support Programme (NESP) has developed a handbook that details the different aspects of workplace safety in small solar installations. ${ }^{86}$ However, design interventions as a strategic tool have not been considered. A group of researchers studied the effects of developing design solutions for workers engaged in the installation of solar PV for small buildings. They collected contextual data from actual projects to identify safety risks and attributes of Prevention through Design (PtD) of the solar roof-top projects such as roofing material, accessories, the slope of the roof, the layout of solar panels, the system of fall protection, lifting methods and other safety factors. They also interacted with contractors and finally developed a solar PtD protocol aimed at reducing workplace risks. ${ }^{60}$ Hong $^{64}$ focused on the importance of incorporating ergonomic design factors in the design of solar PV panels. He proposes the incorporation of functional design, interface design, color design, ergonomics factors, surface material, and structural elements in the final product design. Electrical safety is an important aspect of FSPV installations because of the proximity of electrical equipment to water and the interface with the workers. Bhang et al $^{66}$ propose a design solution for underwater grounding for FSPV projects based on the lowest water temperature. Such design interventions are expected to ultimately protect workers against electrocution, especially when electrical risks are unseen. Balo and Şağbanşua ${ }^{69}$ insist that solar panels' selection should consider customer satisfaction, electrical, mechanical, financial, and environmental parameters. The learnings from these design approaches can be applied in the FSPV sector to plan appropriate ergonomics design interventions.

\section{Design as a Strategy for Risk Mitigation}

An important objective of design is to prevent deleterious effects and drudgery in the workplace through appropriate interventions. For example, occupational falls can be greatly reduced or prevented by aiding balance recovery through the design of footwear (to prevent falls on slippery floats), walkway handrails (to prevent falls in the water), and other aspects of task design. ${ }^{87}$ The design interventions must be contextual and address the risk factors in a manner that ensures a comfortable and safe work environment since every injury or accident comes at a high price for all stakeholders. Design intervention is an effective way of addressing these issues before the occupational risk factors become uncontrollable.

This review indicates several ergonomics design interventions for addressing the occupational risk factors in the installation and maintenance of floating solar photovoltaic projects. They include innovative tools, lowering of loads, redesigning workplace layouts, introducing job aids, automation, task rotation, training, OSH standards, job enlargement, and changes in work organization/shift. 
Jobs in the renewable energy industry fall in the category of "green jobs" ${ }^{88}$ Schulte et al ${ }^{89}$ have argued that although such jobs are referred to as green jobs, the workers performing them are not necessarily safe as they are exposed to a host of occupational risks, some of which have been described earlier. They recommend adopting the strategy of "designing out the hazards" to address such issues. Hanson $^{90}$ emphasized the need for workplace design and Personal Protective Equipment (PPE) to protect workers engaged in installing solar panels in hot climatic conditions. Designing out risks in green jobs is critically important by ideally involving the worker in risk assessment and the complete design process by considering physical, cognitive, and organizational factors. Figure 5 shows a suggested strategy to implement design interventions in the FSPV sector. Stakeholders can use the template to plan and execute interventions using a participative approach. To ensure the sustainability of the job, a tool consisting of 40 occupational health indicators for monitoring of green jobs in Portugal based on the framework "Health indicators of sustainable jobs" of the World Health Organization (WHO) can also be used in the FSPV sector. ${ }^{91}$

The review outcomes support the urgent need for interventions given the growing size of the FSPV sector and context-specific occupational risks associated with installation and maintenance. This study also highlights several research gaps/opportunities for addressing the risk factors from an ergonomics design perspective (Figure 4).

It is also proposed that OSH issues are closely linked to several SDGs of the UNDP. Therefore, sustainability initiatives should also address the safety and health concerns of the workers engaged in the FSPV sector. Moreover, if the OSH issues are addressed, FSPV projects are expected to be the most preferred and affordable (by avoiding OSH costs) source of clean and sustainable energy within the solar PV industry.

\section{Limitations of the Study}

The online bibliographic databases considered for this scoping review were limited to Science Direct, Google Scholar, Web of Science, and Scopus based on the study design. Another limitation is that only published papers in the English language were considered.

\section{Conclusion}

The present review focussed mainly on the emerging OSH issues in the installation and maintenance aspects of the floating solar PV projects. Within the solar PV industry,
FSPV installations are new and evolving workplaces with a host of occupational risk factors that have not been adequately recognized and addressed. Immediate attention should be given to controlling these risk factors by the stakeholders before the workers start developing musculoskeletal disorders, suffer from effects of solar radiation affecting the skin and eyes, heat illnesses, burn injuries, psychosocial problems, and other deleterious health conditions. The current scoping review reveals some important themes and future scope that need to be considered to achieve SDGs successfully. These include the following points:

a) FSPV projects are new workplaces with emerging occupational hazards (distinct from occupational risks in other solar PV installations). The impacts of these hazards are needed to be further investigated and addressed.

b) The prevailing occupational risks are diverse and may affect the workers individually or in combination (eg, carrying a heavy solar PV panel on an unstable floating platform in hot and humid temperatures).

c) This review has identified various research gaps that might be addressed by involving all the stakeholders through appropriate ergonomics design interventions (Figure 4).

d) There is a need for exploring the efficacy of different interventions and their relationships/mediating roles with safety, productivity, and cost-effectiveness (Figure 4).

e) Further, there are opportunities for the development of universal training and global OSH standards (especially for electrical safety) specific to the floating solar PV sector.

The current paper is the first of its kind effort to review the emerging OSH issues in the FSPV sector where there are significant knowledge gaps and proposes future scope for ergonomics design solutions. These interventions are positively linked to the attainment of several SDGs and must be taken up for a sustainable FSPV sector. This review is intended to arouse interest among different stakeholders such as industrial designers, manufacturers, investors, project developers, energy suppliers, health and safety professionals, ergonomists, training entities, and policymakers to encourage/motivate them to contribute in their own ways to ensure sustainable development.

\section{Acknowledgment}

The authors acknowledge the infrastructural facilities and library resources provided by the Indian Institute of Technology (IIT) Guwahati, Assam, India. 


\section{Author Contributions}

All authors made substantial contributions to conception and study design, data acquisition, analysis and interpretation of data, drafting the article or revising it critically for important intellectual content, and agreed to submit it to the current journal. They gave final approval of the version to be published; and agree to be responsible and accountable for all aspects and content of the work.

\section{Funding}

This research has received no funding.

\section{Disclosure}

The authors report no conflicts of interest in this work.

\section{References}

1. International Renewable Energy Agency. Future of solar photovoltaic: deployment, investment, technology, grid integration and socio-economic aspects; November, 2019. Available from: https:// www.irena.org/publications/2019/Nov/Future-of-Solar-Photovoltaic. Accessed December 6, 2020.

2. Sahu A, Yadav N, Sudhakar K. Floating photovoltaic power plant: a review. Renew Sustain Energy Rev. 2016;66:815-824. doi:10.1016/j. rser.2016.08.051

3. International Bank for Reconstruction and Development/World Bank. Floating solar handbook for practitioners-where sun meets water; October, 2019. Available from: https://openknowledge.worldbank. org/handle/10986/32804. Accessed November 10, 2020.

4. Stack T, Ostrom LT. Occupational Ergonomics: A Practical Approach. New Jersey: John Wiley \& Sons; 2016.

5. Bridger RS. Introduction to Human Factors and Ergonomics. 4th ed. Boca Raton: CRC Press; 2018.

6. National Research Council and Institute of Medicine. Musculoskeletal Disorders and the Workplace: Low Back and Upper Extremities. Washington, DC: The National Academies Press; 2011. doi:10.17226/10032

7. Health and Safety Executive. Work related musculoskeletal disorders in Great Britain (WRMSDs); October, 2019. Available from: https:// www.hse.gov.uk/statistics/causdis/msd.pdf. Accessed August 6, 2020.

8. Modenese A, Korpinen L, Gobba F. Solar radiation exposure and outdoor work: an underestimated occupational risk. Int J Environ Res Public Health. 2018;15(10):1-24. doi:10.3390/ijerph15102063

9. Bellini E. Japan's largest floating PV plant catches fire after typhoon faxai impact. pv magazine; September, 2019. Available from: https:// www.pv-magazine.com/2019/09/09/japans-largest-floating-pv-plantcatches-fire-after-typhoon-faxai-impact. Accessed December 9, 2020.

10. United Nations Development Programme. Sustainable development goals. Available from: https://www.undp.org/content/undp/en/home/ sustainable-development-goals.html. Accessed June 2, 2020.

11. Gilding P, Hogarth M, Humphries R. Safe companies: an alternative approach to operationalizing sustainability. Corp Environ Strategy. 2002;9(4):390-397. doi:10.1016/S1066-7938(02)00108-2

12. Hajmohammad S, Vachon S. Safety culture: a catalyst for sustainable development. J Bus Ethics. 2014;123(2):263-281. doi:10.1007/ s10551-013-1813-0

13. Jilcha K, Kitaw D. Industrial occupational safety and health innovation for sustainable development. Int J Eng Sci Technol. 2017;20 (1):372-380. doi:10.1016/j.jestch.2016.10.011
14. Nawaz W, Linke P, Koç M. Safety and sustainability nexus: a review and appraisal. J Clean Prod. 2019;216:74-87. doi:10.1016/j. jclepro.2019.01.167

15. SolarPower Europe. Operation \& maintenance best practice guidelines; December, 2019. Available from: https://www.solarpowereu rope.org/om-best-practice-guidelines-version-4-0/. Accessed December 1, 2020.

16. European Agency for Safety and Health at Work. Green jobs and occupational safety and health: foresight on new and emerging risks associated with new technologies by 2020; April, 2013. Available from: https://osha.europa.eu/en/publications/green-jobs-andoccupational-safety-and-health-foresight-new-and-emerging-risks /view. Accessed January 10, 2021.

17. European Agency for Safety and Health at Work. OSH and small-scale solar energy applications; May, 2013. Available from: e-fact 68: OSH and small-scale solar energy applications - Safety and health at work - EU-OSHA (europa.eu). Accessed March 1, 2021.

18. Moher D, LiberatiA, Tetzlaff J, Altman DG. Preferred reporting items for systematic reviews and meta-analyses: the PRISMA statement. Ann Intern Med. 2009;151:264-269.

19. Goswami A, Sadhu P, Goswami U, Sadhu PK. Floating solar power plant for sustainable development: a techno-economic analysis. Environ Prog Sustain Energy. 2019;38(6). doi:10.1002/ep.13268

20. Liu L, Wang Q, Lin H, Li H, Sun Q, Wennersten R. Power generation efficiency and prospects of floating photovoltaic systems. Energy Procedia. 2017;105:1136-1142. doi:10.1016/j. egypro.2017.03.483

21. Sahu AK, Sudhakar K. Effect of UV exposure on bimodal HDPE floats for floating solar application. J Mater Res Technol. 2019;8 (1):147-156. doi:10.1016/j.jmrt.2017.10.002

22. Azami S, Vahdaty M, Torabi F. Theoretical analysis of reservoir-based floating photovoltaic plant for 15-khordad dam in Delijan. Energy Equip Syst. 2017;5(2):211-218. doi:10.22059/ ees. 2017.25760

23. Mittal D, Saxena BK, Rao KVS. Comparison of floating photovoltaic plant with solar photovoltaic plant for energy generation at Jodhpur in India. Proceedings of the International Conference on Technological Advancements in Power and Energy (TAP Energy); 2018:1-6. doi: 10.1109/TAPENERGY.2017.8397348.

24. Rosa-Clot M, Tina GM, Nizetic S. Floating photovoltaic plants and wastewater basins: an Australian project. Energy Procedia. 2017;134:664-674. doi:10.1016/j.egypro.2017.09.585

25. Ferrer-Gisbert C, Ferrán-Gozálvez JJ, Redón-Santafé M, FerrerGisbert P, Sánchez-Romero FJ, Torregrosa-Soler JB. A new photovoltaic floating cover system for water reservoirs. Renew Energy. 2013;60:63-70. doi:10.1016/j.renene.2013.04.007

26. Cazzaniga R, Rosa-Clot M, Rosa-Clot P, Tina GM. Integration of PV floating with hydroelectric power plants. Heliyon. 2019;5(6):e01918. doi:10.1016/j.heliyon.2019.e01918

27. Pringle AM, Handler RM, Pearce JM. Aquavoltaics: synergies for dual use of water area for solar photovoltaic electricity generation and aquaculture. Renew Sustain Energy Rev. 2017;80 (December2016):572-584. doi:10.1016/j.rser.2017.05.191

28. Trapani K, Millar DL. Proposing offshore photovoltaic (PV) technology to the energy mix of the Maltese islands. Energy Convers Manag. 2013;67:18-26. doi:10.1016/j.enconman.2012.10.022

29. Kamenopoulos SN, Tsoutsos T. Assessment of the safe operation and maintenance of photovoltaic systems. Energy. 2015;93:1633-1638. doi:10.1016/j.energy.2015.10.037

30. Samaniego-Rascón D, Gameiro da Silva MC, Ferreira AD, Cabanillas-Lopez RE. Solar energy industry workers under climate change: a risk assessment of the level of heat stress experienced by a worker based on measured data. Saf Sci. 2019;118 (June2018):33-47. doi:10.1016/j.ssci.2019.04.042 
31. White JR, Doherty M. Hazards in the installation and maintenance of solar panels. Proceedings of the IEEE IAS Electrical Safety Workshop (ESW); 2017:1-5. doi:10.1109/ESW.2017.7914834

32. Wybo JL. Large-scale photovoltaic systems in airports areas: safety concerns. Renew Sustain Energy Rev. 2013;21:402-410. doi:10.1016/ j.rser.2013.01.009

33. Bakhiyi $\mathrm{B}$, Labrèche $\mathrm{F}$, Zayed $\mathrm{J}$. The photovoltaic industry on the path to a sustainable future - environmental and occupational health issues. Environ Int. 2014;73:224-234. doi:10.1016/j. envint.2014.07.023

34. Falvo MC, Capparella S. Safety issues in PV systems: design choices for a secure fault detection and for preventing fire risk. Case Stud Fire Saf. 2015;3:1-16. doi:10.1016/j.csfs.2014.11.002

35. Dhere NG, Shiradkar NS. Fire hazard and other safety concerns of photovoltaic systems. $J$ Photonics Energy. 2012;2(1):1-14. doi:10.1117/12.893927

36. Fthenakis VM, Moskowitz PD. Photovoltaics: environmental, health and safety issues and perspectives. Prog Photovoltaics Res Appl. 2000;8(1):27-38. doi:10.1002/(SICI)1099-159X(200001/02)8:1<27:: AID-PIP296>3.0.CO;2-8

37. Aman MM, Solangi KH, Hossain MS, et al. A review of Safety, Health and Environmental (SHE) issues of solar energy system. Renew Sustain Energy Rev. 2015;41(58):1190-1204. doi:10.1016/j. rser.2014.08.086

38. Fernandez CA, Moore K, McClure LA, et al. Occupational psychosocial hazards among the emerging US green collar workforce. $J$ Occup Environ Med. 2017;59(1):1-5. doi:10.1097/ JOM.0000000000000903

39. Cavalli L, Jeebhay MF, Marques F, et al. Scoping global aquaculture occupational safety and health. J Agromedicine. 2019;24(4):391-404. doi:10.1080/1059924X.2019.1655203

40. de Oliveira PK, Cavalli RS, Kunert Filho HC, et al. Occupational health and safety in aquaculture: insights on Brazilian public policies. J Agromedicine. 2017;22(2):148-158. doi:10.1080/ 1059924X.2017.1283275

41. Mitchell RJ, Lystad RP. Occupational injury and disease in the Australian aquaculture industry. Mar Policy. 2019;99 (October2018):216-222. doi:10.1016/j.marpol.2018.10.044

42. Ngajilo D, Jeebhay MF. Occupational injuries and diseases in aquaculture - a review of literature. Aquaculture. 2019;507 (March):40-55. doi:10.1016/j.aquaculture.2019.03.053

43. Barlas B, Izci FB. Individual and workplace factors related to fatal occupational accidents among shipyard workers in Turkey. Saf Sci. 2018;101(September2017):173-179. doi:10.1016/j. ssci.2017.09.012

44. Wang Y, Zhan S, Liu Y, Li Y. Occupational hazards to health of port workers. Int J Occup Saf Ergon. 2017;23(4):584-588. doi:10.1080/ 10803548.2016.1199501

45. Fulmer S, Buchholz B, Scribani M, Jenkins P. Musculoskeletal disorders in Northeast Lobstermen. Saf Health Work. 2017;8 (3):282-289. doi:10.1016/j.shaw.2016.12.004

46. Cha SG, Byun YS, Jeon MJ, Sakong J. Diving patterns and decompression sickness among South Korean fishery divers. J Occup Health. 2019;61(1):143-153. doi:10.1002/1348-9585.12035

47. Oldenburg M, Kuechmeister B, Ohnemus U, Baur X, Moll I. Actinic keratosis among seafarers. Arch Dermatol Res. 2013;305(9):787-796. doi:10.1007/s00403-013-1384-z

48. Modenese A, Ruggieri FP, Bisegna F, et al. Occupational exposure to solar UV radiation of a group of fishermen working in the Italian north adriatic sea. Int $J$ Environ Res Public Health. 2019;16 (16):1-12. doi:10.3390/ijerph16163001

49. Brooks C, Urmee T. Importance of individual capacity building for successful solar program implementation: a case study in the Philippines. Renew Energy. 2014;71:176-184. doi:10.1016/j. renene.2014.05.016
50. Middleton P, McIntosh J. Skill needs for the solar energy workforce. In: 30th ISES Biennial Solar World Congress. Vol. 2; 2011:998-1007. Available from: http://proceedings.ises.org/paper/ swc2011/swc2011-0050-McIntosh.pdf. Accessed March 27, 2021.

51. Mrohs M. Rural electrification. Prog Photovoltaics Res Appl. 1998;6 (5):307-313. doi:10.1002/(SICI)1099-159X(1998090)6:5<307::AIDPIP240>3.0.CO;2-Y

52. Pavlova M. Emerging environmental industries: impact on required skills and TVET systems. Int J Train Res. 2019;17(sup1):144-158. doi:10.1080/14480220.2019.1639276

53. Tsoutsos TD, Tournaki SK, Gkouskos ZK, Despotou E, Masson G. Training and certification of PV installers in Europe. Renew Energy. 2013;49(2013):222-226. doi:10.1016/j.renene.2012.01.027

54. Lucas H, Pinnington S, Cabeza LF. Education and training gaps in the renewable energy sector. Sol Energy. 2018;173(July):449-455. doi:10.1016/j.solener.2018.07.061

55. Goel M. Solar roof-top in India: policies, challenges and outlook. Green Energy Environ. 2016;1(2):129-137. doi:10.1016/j. gee.2016.08.003

56. OSHA (Occupational Safety and Health Administration). Regulations (standards - 29 CFR), United States department of labor. Available from: https://www.osha.gov/laws-regs/regulations/standardnumber/ 1926. Accessed December 28, 2020.

57. State of Queensland. Construction and operation of solar farms. Code of practice 2019; May, 2019. Available from: https://www.worksafe. qld.gov.au/_data/assets/pdf_file/0003/174396/construction-andoperation-of-solar-farms-cop.pdf. Accessed January 24, 2021.

58. City of Newport Beach. Guidelines (guideline D.04) on fire safety elements of solar photovoltaic systems; December, 2009. Available from: https://www.newportbeachca.gov/home/showdocument?id= 10545. Accessed March 10, 2020.

59. Dai J, Zhang C, Lim HV, et al. Design and construction of floating modular photovoltaic system for water reservoirs. Energy. 2020;191:116549. doi:10.1016/j.energy.2019.116549

60. Ho C, Lee HW, Gambatese JA. Application of Prevention through Design (PtD) to improve the safety of solar installations on small buildings. Saf Sci. 2020;125:104633. doi:10.1016/j. ssci.2020.104633

61. Li HX, Zhang Y, Edwards D, Hosseini MR. Improving the energy production of roof-top solar PV systems through roof design. Build Simul. 2020;13(2):475-487. doi:10.1007/s12273-019-0 585-6

62. Bao Q, Sinitskaya E, Gomez KJ, MacDonald EF, Yang MC. A human-centered design approach to evaluating factors in residential solar PV adoption: a survey of homeowners in California and Massachusetts. Renew Energy. 2020;151:503-513. doi:10.1016/j. renene.2019.11.047

63. Hernández-Callejo L, Gallardo-Saavedra S, Alonso-Gómez V. A review of photovoltaic systems: design, operation and maintenance. Sol Energy. 2019;188(March):426-440. doi:10.1016/j. solener.2019.06.017

64. Hong W. Analysis of the constituent elements in the design of solar photovoltaic products. IOP Conf Ser Earth Environ Sci. 2019;252:032075. doi:10.1088/1755-1315/252/3/032075

65. Cazzaniga R, Cicu M, Rosa-Clot M, Rosa-Clot P, Tina GM, Ventura C. Floating photovoltaic plants: performance analysis and design solutions. Renew Sustain Energy Rev. 2018;81 (14):1730-1741. doi:10.1016/j.rser.2017.05.269

66. Bhang B, Kim G, Cha H, et al. Design methods of underwater grounding electrode array by considering inter-electrode interference for floating PVs. Energies. 2018;11(4):982. doi:10.3390/en11040982

67. Bao Q, Honda T, El Ferik S, Shaukat MM, Yang MC. Understanding the role of visual appeal in consumer preference for residential solar panels. Renew Energy. 2017;113:1569-1579. doi:10.1016/j. renene.2017.07.021 
68. Kim S-H, Yoon S-J, Choi W. Design and construction of 1 MW class floating PV generation structural system using FRP members. Energies. 2017;10(8):1142. doi:10.3390/en10081142

69. Balo F, Şağbanşua L. The selection of the best solar panel for the photovoltaic system design by using AHP. Energy Procedia. 2016;100:50-53. doi:10.1016/j.egypro.2016.10.151

70. Scognamiglio A. Photovoltaic landscapes: design and assessment. A critical review for a new transdisciplinary design vision. Renew Sustain Energy Rev. 2016;55:629-661. doi:10.1016/j. rser.2015.10.072

71. Lee Y-G, Joo H-J, Yoon S-J. Design and installation of floating type photovoltaic energy generation system using FRP members. Sol Energy. 2014;108:13-27. doi:10.1016/j.solener.2014.06.033

72. Spertino F, Corona F. Monitoring and checking of performance in photovoltaic plants: a tool for design, installation and maintenance of grid-connected systems. Renew Energy. 2013;60:722-732. doi:10.1016/j.renene.2013.06.011

73. Norman D. The Design of Everyday Things. Revised and Expanded Edition. New York: Basic Books; 2013.

74. Ranjbaran P, Yousefi H, Gharehpetian GB, Astaraei FR. A review on floating photovoltaic (FPV)power generation units. Renew Sustain Energy Rev. 2019;110(April):332-347. doi:10.1016/j. rser.2019.05.015

75. ILO. Working on a warmer planet: the effect of heat stress on productivity and decent work; July, 2019. Available from: https:// www.ilo.org/global/publications/books/WCMS_711919/lang-en/ index.htm\#: :text=The $\% 20$ phenomenon $\% 20$ of $\% 20$ heat $\% 20$ stress, major $\% 20$ consequences $\% 20$ of $\% 20$ global $\% 20$ warming.\&text $=$ This $\%$ 20 report $\% 20$ shows $\% 20$ the $\% 20$ impact,all $\% 20$ countries $\% 20 \mathrm{in} \% 20$ the \%20world. Accessed April 7, 2021.

76. Kim D, Lee J. Spatial changes in work capacity for occupations vulnerable to heat stress: potential regional impacts from global climate change. Saf Health Work. 2020;11(1):1-9. doi:10.1016/j. shaw.2019.10.004

77. Paulo MS, Adam B, Akagwu C, et al. WHO/ILO work-related burden of disease and injury: protocol for systematic reviews of occupational exposure to solar ultraviolet radiation and of the effect of occupational exposure to solar ultraviolet radiation on melanoma and non-melanoma skin cancer. Environ Int. 2019;126 (May2018):804-815. doi:10.1016/j.envint.2018.09.039

78. Reinau D, Weiss M, Meier CR, Diepgen TL, Surber C. Outdoor workers' sun-related knowledge, attitudes and protective behaviours: a systematic review of cross-sectional and interventional studies. $\mathrm{Br}$ $J$ Dermatol. 2013;168(5):928-940. doi:10.1111/bjd.12160

79. Widanarko B, Legg S, Stevenson M, et al. Prevalence of musculoskeletal symptoms in relation to gender, age, and occupational/industrial group. Int $J$ Ind Ergon. 2011;41(5):561-572. doi:10.1016/j. ergon.2011.06.002
80. Behroozy A, Keegel TG. Wet-work exposure: a main risk factor for occupational hand dermatitis. Saf Health Work. 2014;5(4):175-180. doi:10.1016/j.shaw.2014.08.001

81. Francis T, Mitchell SJ. Pathophysiology of decompression sickness. In: Brubakk AO, Neuman TS, editors. Bennett and Elliott's Physiology and Medicine of Diving. 5th ed. London, UK: Saunders; 2003:530-556.

82. Bellini E. Floating PV systems are storm-resistant. pv magazine; November, 2020. Available from: https:/www.pv-magazine.com/ 2020/11/06/floating-pv-systems-are-storm-resistant/Published. Accessed March 1, 2021.

83. Camuffo A, De Stefano F, Paolino C. Safety reloaded: lean operations and high involvement work practices for sustainable workplaces. J Bus Ethics. 2017;143(2):245-259. doi:10.1007/ s10551-015-2590-8

84. Haynes E, Kramer DM, Strahlendorf P, Holness DL, Kushner R, Tenkate T. A cross-Canada knowledge transfer and exchange workplace intervention targeting the adoption of sun safety programs and practices: sun safety at work Canada. Saf Sci. 2018;102 (May2017):238-250. doi:10.1016/j.ssci.2017.10.013

85. OSEIA (Oregon Solar Industries Association). Solar construction safety. Available from: https://www.coshnetwork.org/sites/default/ files/OSEIA Solar Safety 12-06.pdf. Accessed January 10, 2021.

86. Isiolaotan $\mathrm{O}_{\text {, And̄osch }} \mathrm{H}$, Städter H. Nigerian Energy Support Programme (NESP). Solar Photovoltaic Installation. 3rd ed. Abuja: Deutsche Gesellschaft für Internationale Zusammenarbeit (GIZ) $\mathrm{GmbH}$; 2017. Available from: https://energypedia.info/images/2/2e/ Solar_PV_Installation_-_Training_Handbook_2017.pdf. Accessed January 15, 2021.

87. Komisar V, McIlroy WE, Duncan CA. Individual, task, and environmental influences on balance recovery: a narrative review of the literature and implications for preventing occupational falls. IISE Trans Occup Ergon Hum Factors. 2019;7(2):91-118. doi:10.1080/ 24725838.2019.1634160

88. ILO. What is a green job? April, 2016. Available from: https://www. ilo.org/global/topics/green-jobs/news/WCMS_220248/lang-en/index. htm. Accessed April 7, 2021.

89. Schulte PA, Heidel D, Okun A, Branche C. Making green jobs safe. Ind Health. 2010;48(4):377-379. doi:10.2486/indhealth.MS4804ED

90. Hanson MA. Green ergonomics: challenges and opportunities. Ergonomics. 2013;56(3):399-408. doi:10.1080/00140139.2012.751457

91. Moreira S, Vasconcelos L, Santos CS. Sustainability of green jobs in Portugal: a methodological approach using occupational health indicators. J Occup Health. 2017;59(5):374-384. doi:10.1539/ joh.17-0045-RA

\section{Publish your work in this journal}

Risk Management and Healthcare Policy is an international, peerreviewed, open access journal focusing on all aspects of public health, policy, and preventative measures to promote good health and improve morbidity and mortality in the population. The journal welcomes submitted papers covering original research, basic science, clinical \& epidemiological studies, reviews and evaluations, guidelines, expert opinion and commentary, case reports and extended reports. The manuscript management system is completely online and includes a very quick and fair peer-review system, which is all easy to use. Visit http://www.dovepress.com/testimonials.php to read real quotes from published authors. 